Fecha de recepción: febrero 2013

Fecha de aceptación: julio 2013

Versión final: diciembre 2014

\section{Representaciones expandidas en puestas contemporáneas}

Catalina Julia Artesi *

Resumen: Este trabajo analiza producciones escénicas locales donde aparece una marcada hibridación. Revisa sus antecedentes: los movimientos de vanguardia que se produjeron en Europa en los comienzos del siglo XX en plena Modernidad, que luego se trasladó a nuestro continente americano. Ya en el siglo XXI se acrecienta la hibridación y el mestizaje cultural.

Se abordan dos tendencias. Por un lado las que resignifican los autores clásicos en puestas que contextualizan problemáticas actuales. Por el otro, la que produce textos propios con el mismo objetivo que la anterior tendencia. En ambos casos, resulta notoria la incidencia de lo mediático y el dominio de una cultura globalizada, que impone a los directores y artistas teatrales sus modelos estéticos- narrativos y su ideología; produciéndose, entonces, la hibridación intermedial o sea el cruce del cuerpo teatral con la virtualidad fílmica que expande la teatralidad.

Palabras clave: formas escénicas liminares - teatralidad expandida - teatro postcolonial.

[Resúmenes en inglés y portugués en la página 46]

${ }^{(*)}$ Profesora y Licenciada en Letras (UBA). Especialista en Ámbitos Educativos y Comunicacionales (UNLP). Profesora e investigadora teatral. Docente en UBA, UP, IUNA e Institutos de Formación Docente. Investigaciones relativas a dramaturgia femenina, teatro argentino y teatro universal.

Es observable en las producciones escénicas porteñas del 2000, durante la primera década y en el comienzo de la segunda, una hibridación genérica muy fuerte. Aparece un colage dramatúrgico variado, inclusive transposiciones genéricas donde se insertan formatos televisivos y materiales audiovisuales o provenientes de la cibernética.

Alan Badiou considera en su ensayo que: "El teatro produce en sí mismo y por sí mismo un efecto de verdad singular, irreductible. Hay una verdad -teatro que no se da en ningún lugar que no sea en el escenario" (Badiou, 2005, p.121).

Ello implica que el texto literario-dramático posea una virtualidad teatral, esté abierto a las posibles representaciones que se realicen en el futuro, donde la idea original de un autor, por una serie de transposiciones escénicas, se convertirá en verdad aunque será una de las tantas formas de concretarla. 
Rescatamos los aportes que realizara Patrice Pavis acerca del mestizaje y de la heterogeneidad de los materiales en el teatro intercultural, propone al crítico teatral hacer compatibles todas las influencias culturales que participan en la puesta en escena contemporánea. Mientras que, la investigadora cubana Ileana Diéguez Caballero, desde un pensar situado en nuestro continente, señala las relaciones entre la liminidad y la hibridación cultural, dando cuenta de su carácter fronterizo (Hommi Bhabha); no obstante, también indica las contradicciones que surgen en nuestros procesos socioculturales pues dan testimonio de conflictos generados en la interculturalidad latinoamericana. Diferentes directores argentinos en los primeros años del siglo XXI han vuelto al teatro de texto para demostrar que existen nuevas miradas y otras modalidades escénicas para abordar autores clásicos como Henrik Ibsen, Antón Chejov o August Strindberg, para citar algunos.

Sin embargo, la incidencia de lo mediático en los tiempos globalizados que corren, impone a los creadores sus modelos estéticos- narrativos y su ideología, tornándose necesario el cruce del cuerpo teatral con la virtualidad filmica. Dicho encuentro tensiona ambas materialidades e induce al espectador contemporáneo a una mayor interactividad en su proceso de interpretación.

Teniendo en cuenta estos planteos, nos preguntamos ¿Por qué la presencia de los géneros híbridos provenientes del cine y de la TV en estas manifestaciones experimentales de la escena local? ¿Por qué necesitan construir una pantalla metaficcional para introducir problemáticas difíciles de tratar en el teatro, sin caer en lo panfletario? Este fenómeno que se ha acrecentado en la Nueva Modernidad da cuenta de los cambios en los "estilos de época", principios interiorizados que dan unidad a las maneras de pensar de cada etapa.

A los fines de comprender esta situación, en primer lugar, nos remontamos al análisis de las vanguardias del siglo XX cuando comenzó a darse lo que Erich Kahler denominó la desintegración de la forma artística (Kahler, 1993, p.79) en cuyo proceso de fragmentación interviene un factor muy importante: "la creciente inseguridad del lenguaje y de la comunicación humana” (Kahler, 1993, p.80).

En segundo lugar, nos proponemos el análisis de una compleja intermedialidad en dos puestas Manifiesto vs. Manifiesto de Susana Torres Molina, co- dirigida por la autora y Marcelo Mangone. Acreedores, que August. Strindberg escribió entre 1888 y 1889, en versión escénica y dramatúrgica (2010) de Marcelo Velásquez. Finalmente, elaboramos nuestras conclusiones acerca estas expresiones.

\section{Discursos artísticos e hibridación}

$\mathrm{Al}$ respecto, nos interesa rescatar la visión de Mijail Bajtin, formalista ruso que hablaba de géneros discursivos que poseen una extrema heterogeneidad, tanto los orales como los escritos (Bajtin, 1982; p. 248), porque estos discursos entran en relación dialógica con otros textos provenientes de la cultura de cada época. Este dialogismo considera, entonces, que toda creación se basa en las relaciones intertextuales con otros discursos, culturales, literarios, sociales, políticos. Bajtin distingue entre géneros discursivos primarios (simples), de los géneros discursivos complejos: 
Los géneros discursivos secundarios (complejos) -a saber novelas, dramas, investigaciones científicas (...) surgen en condiciones de comunicación mas compleja (...) En el proceso de su formación estos géneros absorben y reelaboran diversos géneros primarios (...).Los géneros primarios que forman parte de los géneros complejos se transforman dentro de estos últimos y adquieren un carácter especial (Bajtin, 1982, p. 250).

Este estudioso ruso distingue una estrecha relación entre estilo y género. Considera que los cambios históricos en los estilos de la lengua están conectados con los cambios de los géneros discursivos. En este contexto la lengua literaria, que incluye los estilos de la lengua no literaria, forma parte de un sistema complejo y organizado (Bajtin, 1982, p.252). Por lo tanto, en cada época del desarrollo de la lengua literaria son determinados géneros los que dan el tono pues hay un estrecho vínculo con la historia de la sociedad.

Esta conceptualización bajtiniana constituye una visión más amplia de la literatura y del arte en relación con otros géneros discursivos. Por ejemplo, Aristóteles en su Poética, definía la tragedia en relación con el cómo imitaba (mimesis de una acción) y lo temático, la idea del destino del héroe en relación con un destino colectivo, dada la importancia de lo jurídico en la conformación de la polis griega.

El cruce de diferentes soportes lingüísticos (TV, cine, radio, libro, CD), se conecta con los conceptos, lo afectivo y lo técnico, e inciden en la forma de pensar y de sentir; a la vez que la forma de pensar y de sentir en una época realimentan los soportes lingüísticos, conceptuales, científicos y técnicos. Existen costumbres mentales (habitus para Pierre Bourdieu), son los principios interiorizados que dan unidad a las maneras de pensar de una época, "los estilos de época", lo que es necesario vincular con diferentes áreas de sentido de cada etapa. Sin embargo, es en las vanguardias del Siglo XX, donde el artista rompe, quiebra, al género y a los estilos. Se acepta el desvío y con él puede aparecer un estilo o un género nuevo. Como dijimos al comienzo, se produce la desintegración de la forma artística (Kahler, 1993, p. 79) debido a que el lenguaje ha perdido jerarquía, ya no comunica. Tal fenómeno se debía a la crisis total que vivía Europa a raíz de los efectos nefastos de la Primera y Segunda Guerra Mundial. Este fenómeno de incomunicación, también fue tratado por los dramaturgos absurdistas de la década del 50.

Según Patrice Pavis, el colage proviene del campo pictórico y fue introducido por los cubistas, los futuristas y los surrealistas, que acercaban dos materiales heteróclitos o bien objetos artísticos y objetos reales (Pavis, 1998, p. 71); es un juego con los significantes, sobre su materialidad, realizando un montaje con fragmentos de textos procedentes de todos los horizontes: artículos de periódicos, otras obras, grabaciones sonoras, etc. (Pavis, 1998, p. 71); dándose una disolución de la forma lingüística.

La literatura y el arte teatral se transforman- véase los caligramas literarios de Guillaume Apollinaire, las composiciones musicales de John Cage, el happening, las perfomances- penetran en el campo de las artes visuales. Esta experimentación de los artistas vanguardistas intensificó el dialogismo al abrir y cruzar los géneros y los estilos, generando rupturas y discontinuidades, apropiándose de todos los terrenos del arte. 
Como los procesos del hombre son simultáneos en la vida moderna, sólo a través de la síntesis puede ser coordinada. Al respecto, Marshal Mc Luhan reconoció que los jóvenes se han formado con la televisión y esto ha producido una gran diferencia con las generaciones anteriores, que habían aprendido a leer y a escribir antes de ser televidentes (Kahler, 1993, p.120). A partir de entonces, los artistas realizan experiencias multisensoriales y multimediales, se busca la integración de los lenguajes. Mc Luhan definió la hibridación de los medios homologándola con una guerra civil, donde "los cruces o las hibridaciones de los medios liberan una enorme fuerza y energía nuevas como si se tratara de un proceso de fisión o fusión" (citado por Horrocks, 2004, p. 70). No es casual que la metáfora empleada por el investigador canadiense provenga de la física nuclear. Símil que conecta el estallido mundial con la relación de tensión en los cruces artísticos. Los movimientos vanguardistas provocan "la destrucción total de la coherencia (...) generando una coherencia que se formará por debajo de la coherencia vieja y decadente" (Kahler, 1993, p. 111). Estas transformaciones se ven intensificadas con la problemática de que la obra de arte es susceptible de reproducción gracias a la aparición de nuevas tecnologías generándose, además, el problema del valor del objeto artístico (Benjamín, 1982, p. 30).

Esta hibridación genérica se profundiza en los medios de comunicación masiva por la incidencia de los nuevos lenguajes que provienen de la cibernética. Este fenómeno ya se venía dando desde la década del 60 cuando en los medios de comunicación permanecían, transformados, los géneros literarios pre-mediáticos.

En la Literatura y en el teatro también se producen transformaciones en su contacto intermedial, especialmente en los que se denomina narrativa hipertextual con la aparición de la literatura hipermedial en los entornos virtuales, publicados en forma digital. Si bien ya existía la literatura interactiva en las producciones de autores fundamentales de la literatura -como Jorge Luís Borges, Julio Cortázar y otros- con el surgimiento de producciones escritas para soportes digitales, la hibridación genérica se va acrecentando. Lo que Mijail Bajtin denominó "cuerpo híbrido" o "cuerpo grotesco".

En este dialogismo de los discursos y de la cultura, cobra importancia la comunicación entendida como práctica sociocultural donde hay una dinámica entre sociedad y cultura, dándose un proceso dinámico en la cultura, donde se construye una práctica significante. Es en esta dinámica cultural donde resulta fundamental la dimensión simbólica, los sujetos se apropian de los bienes culturales y se expresan mediante prácticas artísticas significantes. En dicho contexto tales prácticas constituyen espacios que movilizan sentidos, incluidos en una trama intertextual e interdiscursiva, donde el objeto estético y el público forman parte de una cultura, generándose procesos complejos de construcción simbólica. Si observamos este fenómeno desde las ciencias sociales y nos situamos en la realidad sociocultural latinoamericana, este proceso de hibridación resulta mucho más complejo. Cuando anteriormente nos referíamos a la metáfora empleada por Mac Luhan para hablar de la hibridación en el arte moderno de aquella época, en realidad estábamos analizando la cultura como "dramatización eufemizada de los conflictos sociales" (García Canclini, 2004, p. 38). Se considera, entonces, el choque de diferentes culturas en una zona fronteri- 
za, donde afloran las conflictivas relaciones interculturales, lo que Ileana Diéguez Caballero denomina "lo liminal" (2007, p. 51) y para Hommni Bhabha constituye un "espacio entre", evidencia del proceso de dominación que sufren los países colonizados (2002), cuyos habitantes viven una especie de exilio interno en sus propios territorios, a tal punto que ha entrado en crisis el concepto de "lo latinoamericano", ¿cómo identificarnos como parte de esta mezcla cultural que somos los hombres y las mujeres de estas latitudes? Según García Canclini (2004, p. 136) estaríamos ante diversas formas de ser latinoamericano, puesto que lo multicultural y las desigualdades en el ejercicio de la ciudadanía, difieren en cada territorio, según cómo se reaccione ante el proceso de globalización.

Volviendo al ámbito teatral, en otro trabajo (Artesi, 2007, p. 1) hemos observado que en el teatro de Buenos Aires de comienzos del siglo XXI, uno de los ejes centrales es la revisión de los paradigmas Tradición-Modernidad que la Generación del 80 había instalado a comienzos del siglo XX; mediante una reapropiación del pasado anticanónica construyen un presente conflictivo desde una visión alternativa a la hegemónica, pues se replantea lo que Elsa Flores Ballestero denomina "las tramas de las identidades modernas de distinto tipo" (Flores Ballestero, 2003, p. 145). Reconocemos como un rasgo en común en estas producciones la presencia de una memoria colectiva fragmentaria y deshistorizada (Martín Barbero, 1991, p. 3). Pareciera que en el corpus que analizamos lo híbrido da cuenta de esta fragmentación pero a la vez integra lo moderno, lo post-moderno y lo pre-urbano mediante la evidencia del "cuerpo grotesco social" del cual habla Bajtin. Tal lo visto en El sabor de la derrota de Sergio Boris, Un amor de Chajarí de Alfredo Ramos, la versión del Juan Moreira que dirigió Eva Halac, El niño argentino de Mauricio Kartum.

Pero no debemos olvidar que el teatro argentino ha sufrido otros cruces con la literatura, el cine, las artes plásticas. Así como el cine argentino en sus intentos de pasar a la sonorización se nutrió de la literatura y del teatro, muchos dramaturgos -Roberto Arlt, Agustín Cuzzani, Sergio de Cecco y otros- incorporaron recursos cinematográficos en sus producciones dramáticas.

Como lo expresamos en nuestro estudio acerca de las relaciones entre el cine y el teatro (Artesi, 2005, p. 3), estos cruces van borrando los límites ficcionales. Nos referimos al fenómeno de la dramaturgia del actor donde en el proceso de producción del espectáculo el intérprete teatral organiza su relato, produciéndose lo que Patrice Pavis denomina opciones dramatúrgicas (Pavis, 1998). Interviene en el proceso de creación con sus improvisaciones, dialoga con textos literarios, fílmicos, pictóricos. Es aquí donde el cine retorna al teatro, mediante el collage, la imbricación poética con otros textos, la fragmentación, los desvíos, similares a los puntos de fuga en un cuadro, producen múltiples sentidos, tal lo que observamos en aquel momento en El sabor de la derrota del Grupo La Bohemia (2005), en cuyo diálogo intertextual con el naturalismo y la gauchesca, sobresalía el cruce con el film El romance del Aniceto y la Francisca (1967) de Leonardo Favio ; el director Sergio Boris resignificaba en su reapropiación, tanto la estética del director mendocino como su matriz argumental, con una visión nihilista posmoderna. 


\section{Video, cuerpo y arte}

Manifiesto Vs. Manifiesto (2008) de Susana Torres Molina, co-dirigida junto a Marcelo Mangone, posee una forma de escritura dramática no tradicional, en cada bloque monodialogan tres performers de un sólo género, hombres que esta vez sí poseen nombres propios tomados de los nombres de los actores (Federico Pavlovsky, Eduardo Misch y Patricio Abadi). Los episodios se alternan con imágenes de videos y fotos reproducidos en una pantalla de un televisor, ubicado en el ángulo derecho del escenario. Sin embargo, hay un enlace entre ambos planos mediante Eduardo, quien interpreta al personaje del video en la escena, expresando palabras del artista suizo o bien haciendo comentarios acerca del mismo reproducida en el video.

El punto de partida de la autora fue una nota aparecida en una revista acerca de Rudolf Shwarzkogler, un vienés que se suicidó durante una última acción artística documentada con su cuerpo. Ella imaginó el manifiesto que este artista podría haber escrito en ese momento y lo alternó con otros manifiestos relativos a personajes locales insertos en situaciones cotidianas donde sus cuerpos también sufren.

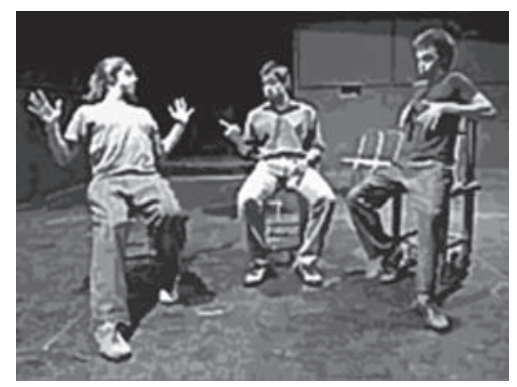

Figura 1. Manifiesto vs Manifiesto. ¿Hasta dónde aguanta un cuerpo? Fuente. www.alternativateatral.com.ar

Con esta puesta Torres Molina plantea interrogantes acerca del arte contemporáneo lo que Silvia Sánchez Urite expresa en su crítica:

¿Hasta dónde aguanta un cuerpo -en el sexo, en la muerte, en la ebriedad? ¿Cuál es el límite para la percepción de los sentidos? Y por otro lado ¿Cualquier cosa que excreta ese cuerpo puede ser considerado arte si es ubicado en un marco institucional como por ej un museo, una obra teatral, el cine, la TV?

¿Hasta dónde llega la sociedad del espectáculo de la que Debord tuvo la premonición? (Sánchez Urite, 2008). 
Esto queda explicitado en un metadiscurso donde se problematiza acerca de las relaciones entre el cuerpo y el arte y, también, sobre las trasgresiones en el arte y sus límites. Tal lo que vemos en una de las secuencias del comienzo de la obra:

PATRICIO / PRESENTADOR: El cuerpo y el Arte se unen en el Body Art. Y la línea más transgresora y violenta de esos movimientos, fue el accionismo vienés desarrollado entre 1965 y 1970. Lo protagonizaron un grupo de artistas casi todos austríacos, los más importantes fueron Gunther Brus. Otto Muhl, Hermann Nitsch y ... Rudolf Schwarzkogler. (Señala a Eduardo). Lo que los distinguía era el uso del propio cuerpo como soporte y los materiales que utilizaban eran sobretodo los fluidos del cuerpo. Sangre, orina, heces, semen. (EN ESCENA HAY CINCO FRASCOS DE VIDRIO) Sus acciones exploraban las zonas prohibidas. Por medio de comportamientos violentos buscaban la revolución total de los sentidos en el público, a través de la animalidad $y$ del dolor.

Con una estructura de alternancia entre acciones en vivo y bloques visuales y audiovisuales acerca de este artista vienés, organiza una historia acerca de los cuerpos de estos personajes; paralelamente, construye un mensaje acerca del arte y del artista. Lo curioso es que en las escenas en vivo aparece un registro lingüístico, la lengua coloquial que caracteriza el habla porteña actual; mientras, que en los manifiestos de Rudolf, utiliza una prosa poética. Este procedimiento ha sido colocado con la intención de que el espectador confronte y medite acerca de estos lenguajes tan dispares.

Como dijimos anteriormente las fotos y los videos ilustran y presentifican mediante la virtualidad al artista vienés:

Patricio/ Presentador habla acerca de las características de sus producciones: Creó imágenes. El cuerpo claustrofóbico, solitario en primer plano.

\section{Video: fotos creadas por Rudolf S. e imágenes de Eduardo como modelo de imágenes similares.}

Las imágenes revelan la unión de la naturaleza con el artificio donde el cuerpo en vivo se transforma en objeto estético; sin embargo, en el body art el cuerpo cobra un sentido opuesto al arte clásico -la armonía de las formas según el canon del arte tradicional-pues los fluidos corporales quiebran la contemplación plácida para generar reacciones diversas en el observador actual. Por eso, en este encadenamiento secuencial, los manifiestos del artista -con su poesía desgarradora y existencial- intentan provocar y sacudir al espectador porteño habituado a la naturalización de la violencia convertida en un espectáculo de los medios. Por ejemplo, en una parte del Primer Manifiesto de Rudolf expresa el actor por qué desarrolla su estética de la crueldad: 
Convivo con esta sensación de asco permanente.

Los pliegues de la condición humana exhalan un hedor paralizante

y ya he permanecido demasiado tiempo impotente

ante los gases de este nuevo campo de exterminio.

En la calle veo cuerpos tirados

con sus caras reventadas contra el asfalto

después de haberse inyectado droga hasta en las venas de los ojos.

Con este discurso surge la idea de un hombre altamente deshumanizado, a tal punto que se ha transformado en un voyeur, caníbal, torturador de los cuerpos en su vida cotidiana y también en los medios donde la realidad en su multiplicidad constituye un simulacro. "El arte como espejo nos devuelve la imagen simultáneamente clara y dura del `ser humanos`, susceptibles de ser víctimas o victimarios, dientes o alimento" (Arango, 2001).

Susana Torres Molina construye una pantalla metaficcional para expresar su visión crítica acerca de las transgresiones extremas en el arte y en los medios; al respecto, citamos un fragmento de un reportaje que la periodista María Agustina Izurieta le hiciera a la dramaturga:

Hay una exacerbación de que lo que no está en la pantalla no existe. Entonces hay que crear situaciones violentas o sexuales para mostrar algo o para ver quién impacta más (...) Pero el lado oscuro siempre ha estado y estará, el ser humano es capaz de las cosas más horripilantes y más maravillosas (Izurieta, 2008).

\section{La interacción entre los medios}

El fenómeno de contaminación y de la hibridación intermedial no constituye un acontecimiento nuevo en el mundo del arte y de la cultura. Los estrechos contactos que se han dado desde el siglo XX entre la historieta, la literatura y la televisión, el cine y el teatro, y en los últimos tiempos con lo multimediático, se han acrecentado aún más en los comienzos del siglo XXI. Es en esta dinámica cultural donde resulta fundamental la dimensión simbólica, los sujetos se apropian de los bienes culturales y se expresan mediante prácticas artísticas significantes. En dicho contexto, tales prácticas constituyen espacios que movilizan sentidos, incluidos en una trama intertextual e interdiscursiva, donde el objeto estético y el público forman parte de una cultura, generándose procesos complejos de construcción simbólica. Los intercambios entre el teatro y los medios de comunicación se puede dar de diferentes maneras, según Patrice Pavis hay que "examinar metódicamente de qué manera un medio influencia a otro medio, por ejemplo un determinado tipo de iluminación cinematográfica puede ser utilizado en el teatro" (Pavis, 1998, p. 251). El investigador francés considera que el cuerpo y el espíritu de los actores y de los espectadores se han modelado debido a la interacción con los medios de comunicación. 
No obstante, la cultura light de los medios televisivos, Gran Hermano por ejemplo, ha desmostrado que el mironismo constituye una subcultura naturalizada donde el espectador puede espiar los hechos más insólitos de la vida privada de cualquier ser humano (Gubern, 2005). De este modo los procedimientos de hibridación que originalmente podían pensarse como búsquedas de nuevos lenguajes y de innovación artística, hoy en día han generado e impuesto un imaginario donde parece imposible la construcción de otras subjetividades.

En la Argentina, este fenómeno ya se venía dando desde la década del 60 cuando en los medios de comunicación permanecían, transformados, los géneros literarios pre-mediáticos que habían sido trasladados al cine, a la televisión, a la radio o a la historieta. A partir de este período, la televisión deviene en dominante económica y cultural (García Canclini, 2004, p. 93), su poder simbólico incide en el campo periodístico, primero, y, en poco tiempo, se expande a otras expresiones inclusive el teatro. Con el liberalismo de los 80 y de los 90 se intensifica por el monopolio de los multimedios.

De otro trabajo nuestro (Artesi, 2005) rescatamos un ejemplo que allí analizamos, una obra de Mariela Asensio donde mediante una estética cercana al kisch, la autora-directora combinaba en Mujeres en el baño (2008) lo melodramático de las series televisivas realizadas al "gusto femenino". Adoptaba el estilo de los talk show: el exhibicionismo de experiencias domésticas, las referencias a figuras paradigmáticas de la música popular, y a los discursos consumistas de los cortos publicitarios. Como ocurre en los programas que parodian a otros programas de la televisión argentina, la puesta reproducía dicho juego de espejos problematizando los íconos femeninos que la sociedad ha espectacularizado.

\section{Acreedores de otras imágenes}

"Este poeta ha visto lo que antes de él y después no vio ninguno: el que la máscara en verdad se había adherido (a la cara) y que lo desnudo sólo podía aparecer bañado en la sangre que provenía del desgarramiento de las capas superiores", estas palabras del dramaturgo estadounidense Eugene O’Neill (1888-1953) revelan los infiernos autobiográficos que dominan las obras del dramaturgo sueco August Strindberg (1849-1912). Si bien al comienzo adhiere a los postulados naturalistas, se aparta de esta poética al combinar procedimientos románticos y simbolistas, con otros recursos precursores del expresionismo, principalmente en sus piezas de un acto de su primera época: Señorita Julia y Acreedores, ambas de 1888.

En ellas aborda la lucha de los sexos aunque profundiza aún más este conflicto al mostrar cómo un ser penetra en otros. Tanto en Camaradas (1886) como en Acreedores relaciona este tema con el arte, sus protagonistas son actrices, pintores y literatos, lo que le permite intercalar metareflexiones acerca de su poética o sobre las problemáticas del creador. En la segunda pieza, una tragicomedia, plantea un triángulo invertido donde Tekla, la esposa, es escritora, Adolfo, su actual esposo, un pintor y el tercero en discordia, su ex marido Gustavo, un profesor de literatura. El dominio donde se libran las grandes batallas -sexo, 
hombre-mujer, amor-odio, vampirismo- constituye el espacio: un hotel ubicado en un balnerario donde la alta burguesía sueca veranea. "Como todo gran dramaturgo, no escribió para su tiempo sino para los venideros. Desde ese lugar siempre incómodo del artista en su contexto de producción, reveló fantasmas que lo asediaban, y aún nos asedian", expresa el director Marcelo Velásquez en el programa de mano.

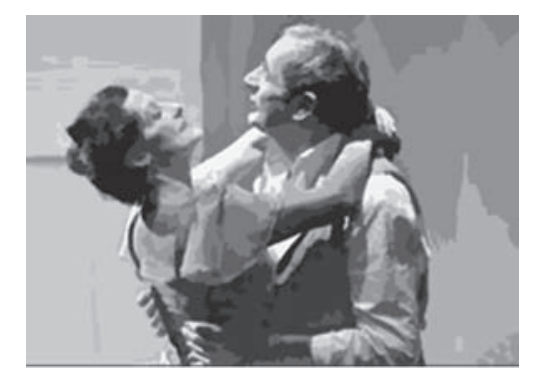

Figura 2. Acreedores. Cómo un ser penetra a otros. Fuente. www.alternativateatral.com.ar

Si bien en la versión que escribieran en su oportunidad Rodolfo Roca y el director la transposición dramatúrgica se basaba en una actualización del lenguaje manteniendo la fidelidad al texto, en la escena hubo cambios. Tal el caso de la eliminación del final donde la muerte de Adolfo no ocurre en el escenario sino que, los actores y el público observan dicho desenlace en una proyección fílmica sobre la pantalla del fondo. Al respecto, citamos otra vez las reflexiones del programa de mano:

Esta nueva puesta en escena de Acreedores quiere dar cuenta de la contemporaneidad de Strindberg. Pretende un corrimiento de los cánones tradicionales del realismo y del naturalismo estéticos en los que se ha categorizado al autor y a parte de su obra. Si en Acreedores se plantea la pregunta acerca de la forma del arte, esta pregunta aún nos guía: ¿Cuál es la forma contemporánea para esta obra de 1888 ? ¿Cuál es la forma que le corresponde al arte de nuestro tiempo?

Por eso en su actualización el director y el escenógrafo han construido una espacio escénico donde se quiebra la caja a la italiana, mediante la inscripción de una figura triangular centrada en una altura tal que brinda una doble perspectiva (arriba-abajo) al espectador sentado en butacas que forman una ele. Este dispositivo escénico traza una diagonal que corta la frontalidad clásica del teatro naturalista y provoca efectos de distancia en el público produciendo un nuevo contexto en el cuerpo teatral pues la intermedialidad introduce una discontinuidad espacio-temporal y provoca nuevas relaciones entre la palabra y la imagen. Tales innovaciones responden a una mirada actual de este clásico, así lo señala el director de esta puesta en su metatexto citado anteriormente: 
Aventuramos en los signos de la puesta en escena algunas respuestas que son nuestro modo de entender la pieza: la inclusión de elementos que interrumpen la acción, la potencian y derriban toda pretensión de ilusión realista, un espacio despojado, mínimo, que anula la posibilidad de los referentes, una actuación distanciada y apoyada en algunos códigos del melodrama y del relato de suspenso, la estilización de la moda en el vestir de finales del siglo XIX, los signos sonoros y musicales anacrónicos. Si Strindberg produce inmerso en una gran crisis finisecular de la representación, la propuesta es, entonces, desmontar la obra para desligarla de lo representativo y, en este juego, hacer visible y no ocultar los hilos que construyen la representación. En este comienzo del siglo XXI, es nuestro modo de acercarnos a la modernidad de Strindberg.

En la relación palabra-imagen la intermedialidad cumple diferentes funciones en la puesta. Por un lado, la muestra de ciertos cuadros significativos de corte impresionista y tenebristas de August Strindberg que estructuran la acción pues inician los cuatro bloques y poseen una función anticipadora de la acción dramática. Por el otro lado, se insertan en cada escena proyecciones de situaciones dramáticas no representadas en la escena viva.

En el primer bloque, especie de prólogo metaficcional, la puesta se abre con dicho dispositivo escenográfico, donde la música y la proyección del cuadro, "Sol sobre mar revuelto", provocan un diálogo sinestésico entre los diversos lenguajes escénicos mientras la voz en off de un locutor (José M. Muscari) introduce reflexiones acerca de la naturaleza del teatro. Inmediatamente, se da la presentación de los personajes mediante una escena virtual donde los tres disfrutan de una agradable velada, prefigurando la temática de la pieza; además, miran a la cámara produciéndose así un pacto ficcional con el espectador que acepta el quiebre de la ilusión teatral. Como ocurre en otras imágenes virtuales, la óptica de narración varía, en este caso es la de Tekla que anticipa una fantasía de la protagonista verbalizada en la acción viva más adelante.

Durante los restantes bloques, escena 1,2 y 3 , el director sigue el continuun dramático de la pieza original, donde se plantea las situaciones de introducción, desarrollo y el desenlace. En la primera escena: los diálogos Adolfo-Gustavo; en la segunda, Adolfo-Tekla ,y en última, Tekla- Gustavo. Si bien la estructura dramática revela relaciones de causa y efecto, aparecen problemáticas propias del naturalismo, en este caso la epilepsia de Adolfo. La introducción de la subjetividad en las diferentes ópticas de narración de las imágenes permite que se rompa con el planteo objetivista del naturalismo del siglo XIX. El director ha realizado una minuciosa lectura del texto original donde ya Strindberg revelaba su intención de innovar el realismo, por ejemplo en sus marcas autobriográficas. El operativo de desmontaje del texto literario mediante la virtualidad escénica, lo concretó teniendo en cuenta los intersticios que ha dejado el dramaturgo en su pieza. De esta manera la deconstrucción de la representación se potencia cuando cruza la materialidad teatral con la virtualidad de la imagen fotográfica y fílmica. El espectador de hoy se encuentra habituado al zapping televisivo, pero de esta lectura hipertextual que plantea la puesta, articula el pasado con su presente. 
Por ejemplo, han seleccionado un leit-motiv musical para identificar al personaje de Tekla código propio del lenguaje cinematográfico. Pero el fragmento musical seleccionado constituye un anacronismo, ya que se inserta una canción del siglo XX, interpretada por la diva francesa Brigitte Bardot, Ciel de lit, donde se asocia al personaje con un ícono del cine francés de los 60, representando así a la mujer fatal y se explicita el motivo del engaño, pero su vez se satiriza la visión misógina del autor. Además, en la pintura insertada al comienzo de la subsecuencia, el cuadro de Strindberg, El faro, revela un paisaje misterioso donde se prefigura lo melodramático de la situación. Ambos intertextos potencian la lectura irónica de la puesta, pero esto depende de la competencia ideológico-cultural del espectador, pues si no conoce la figura de la diva del cine, realiza otras lecturas.

En las dos últimas escenas van incrementándose las imágenes subjetivas en función de la progresión dramática. Por ejemplo, la escena III, cuando el acreedor cumple su objetivo de venganza, el guión de filmación expresa: "Pintura de Strindberg: The Town. Es una pintura oscura, muy tormentosa. Comienzo de la escena final y el camino del desenlace de la tragedia-desenmascaramiento, caída del plan de Gustavo". En todas las imágenes pictóricas se muestra un paisaje desde un plano general como en una galería; no obstante, inician un diálogo contrapuntístico con las secuencias fílmicas, donde aparecen imágenes de los personajes en su calidad de espiones de la acción, tal lo expresado en el guión antes del final: "Subjetiva de Adolfo (ojo de Adolfo) que ve la escena de seducción entre su esposa y Gustavo. Adolfo se entera de quién es realmente Gustavo". Las imágenes tomadas con una lente "ojo de pez", junto al primer plano del ojo de la víctima, están en función dramática respecto de la trama trágico-melodramática.

Sin embargo, el diálogo intertextual dentro de la escena cambia diametralmente en la subsecuencia de la muerte de Adolfo: "Se juntan las tres subjetivas para reemplazar en pantalla el final de la obra de Strindberg. Tekla que corre a la habitación para ver qué le sucedió al marido, Adolfo que ve, desde el suelo, acercarse a su mujer. Gustavo que mira apartado la escena entre Adolfo y Tekla". El cruce de las subjetivas aumenta en el espectador su capacidad de lectura. Aunque la escena final donde "Gustavo y Tekla observan como espectadores el final de la obra," abre una instancia metaficcional donde el desmontaje escénico relaciona distintos cuerpos de textos- la escena viva y la virtualidad- abre un juego hacia otras relaciones hipertextuales generando un verdadero espectador activo pero también la posibilidad de otros desmontajes.

\section{Conclusiones}

Hemos revisado cómo en pleno siglo XX , debido a la desintegración del lenguaje y a la crisis de comunicación, las vanguardias europeas han profundizado el largo proceso de hibridación en las artes, que Mijail Bajtin había estudiado en épocas anteriores.

Sin embargo, el fenómeno adquiere rasgos particulares en el arte latinoamericano de las últimas décadas del siglo pasado, donde las expresiones fronterizas muestran el grado de tensión social que vivimos, motivada por el poder de la cultura hegemónica foránea sobre las culturas mestizas de nuestros países. 
$\mathrm{Al}$ revisar la situación del arte y de los medios en la Nueva Modernidad, ya iniciado el siglo XXI, hallamos que la televisión ha cobrado un poder simbólico tal que ha espectacularizado la vida cotidiana del televidente y del resto de los niveles de la sociedad. A tal punto, que los formatos cinematográficos y televisivos, en su proceso de hibridación constante, se han mixturado con los lenguajes artísticos pues el ser humano actual piensa y se expresa con imágenes electrónicas. Estos soportes electrónicos permiten la expansión de la teatralidad. No sólo espectacularizan la puesta, también revelan los cambios sufridos en nuestro subcontinente y los procesos de hibridación cultural.

Por un lado, vimos en Manifiesto vs. Manifiesto que esta situación lleva a los artistas a utilizar las imágenes y los códigos televisivos, conformando una especie de pictogramas escénicos, donde el cuerpo del actor interactúa y adopta los lenguajes tecnológicos quedando la palabra desplazada en un plano secundario. En este caso estos lenguajes plantean una aguda crítica hacia la sociedad mercantilizada que presiona al artista. Cuestionando, de este modo, los límites éticos que deberían darse.

Por el otro lado, Marcelo Velázquez aprovecha el juego escénico y sugiere otras cuestiones: la visión crítica acerca de esta nueva Modernidad del siglo XXI. La estructura en espejo del final alude a la situación del hombre contemporáneo. Los medios televisivos proponen, mediante programaciones que inducen el consumismo, una especie de hipnosis en el espectador. Convertido éste en un espión morboso, mira por el ojo de la cerradura la vida privada de sujetos comprados para ser espiados a cambio de popularidad y fama. La morbidez, a la inversa, se transforma en una cultura para el hombre de la calle que exhibe su privacidad en imágenes públicas. Como "el medio es el mensaje"-según Marshall MC Luhan (1996) - sólo podemos transmitir nuestros mensajes a través de los medios audiovisuales. De lo contrario no existimos.

Finalmente, siguiendo a Hommi Bhabha, por medio de una especie de spanglish escénico, "espacio entre", se patentiza la tensión centro-periferia, en un proceso donde aparecen múltiples identidades, o sea el "cuerpo grotesco" de la sociedad (Bajtin, 1982).

\section{Referencias Bibliográficas}

Arango, L. M. (2001). El cuerpo extraño: cuerpo vs. tecnología en el territorio del arte, en Revista Antioquia No 265, jul-set.

Artesi, C. J. (2007), Lo urbano y lo pre-urbano en el teatro actual de Buenos Aires. En Actas del XIV Congreso Nacional de Literatura Argentina., Universidad Nacional de Cuyo (Mendoza, 26-28 de julio de 2007).Universidad Nacional de Cuyo, Facultad de Filosofía y Letras/Ministerio de Turismo y Cultura/CONICET/ Academia Argentina de Letras.

(2005). Diálogo entre el cine y el teatro en El sabor de la derrota del grupo La Bohemia. En, Revista Digital Telóndefondo (DIR. Beatriz Trastoy), Buenos Aires, año III, No 5, julio. Disponible en www.telondefondo.org.ar

Badiou, A. (2005). Imágenes y palabras. Escritos sobre cine y teatro. Buenos Aires: Manantial. Bajtin, M.(1982). Estética de la creación verbal. México: Siglo XXI.

Bhabha, H. K. (2002). El lugar de la cultura. Buenos Aires: Manantial. 
Diéguez Caballero, I. (2005). Escenarios liminares. Teatralidades, perfomances y política. Buenos Aires: Atuel.

Flores Ballestero, E. (2003). Globalización e identidad cultural” En Globalización e Identidad Cultural (Bayardo, R y Lacarreu, M., comp.), Buenos Aires.

García Canclini, N. (2004). Diferentes, desiguales y desconectados. Mapas de la interculturalidad. Barcelona: Gedisa.

Horrocks, C. (2004). Marshall Mc Luhan y la realidad virtual. Barcelona: Gedisa.

Izurieta, M. A. (2008). Hay falsedades que son muy verdaderas en Revista Asterisco, suplemento cultural de semanario Sur, Año 2, No 64, junio.

Kahler, E. (1993). La desintegración de la forma en las artes. México: Siglo XXI.

Mac Luhan, M. (1996). Comprender los medios de comunicación: las extensiones del ser humano. Barcelona: Paidós.

Martín Barbero, J. (1991). La cultura en la comunicación en América Latina. Primer Encuentro de Almagro, Universidad Complutense de Madrid.

Pavis, P. (1998). Diccionario de teatro. Dramaturgia, estética, semiología. Buenos Aires: Paidós. Sánchez Urite, S. (2008). Manifiesto vs. Manifiesto: El cuerpo en situación límite (mimeo).

Summary: This paper analyzes local stage productions where it appears a strong hybridization. In addition, it revises his background: garde movements that occurred in Europe in the early twentieth century in full Modernity, which then moved to our American continent. Already in the XXI century is increased hybridization and cultural mixing. Two trends are addressed. On the one hand they redefine classical authors in stagings that contextualize current issues. On the other, it produces texts themselves with the same aim as the previous trend. In both cases, it is evident the incidence of the media and the dominance of a globalized culture, which imposes directors and theater artists their aesthetic and narrative models and ideology; producing then the intermedia hybridization, meaning, the crossing of the theatrical body with virtuality that expands the theatrical film.

Keywords: expanded theatricality - liminal scenic forms - postcolonial theater.

Resumo: este trabalho analisa produções cênicas locais onde aparece uma marcada hibridação. Revisa seus antecedentes: os movimentos de vanguarda produzidos na Europa nos começos do século XX em plena Modernidade, que depois se transladou ao nosso continente americano. Já no século XXI se acrescenta a hibridação e a mestiçagem cultural. Abordam-se duas tendências. Por um lado as que re-significam os autores clássicos em postas que contextualizam problemáticas atuais. Por outro, a que produz textos próprios com o mesmo objetivo que a anterior tendência. Nos dois casos, resulta notória a incidência do mediático e o domínio de uma cultura globalizada, que impõe aos diretores e artistas teatrais seus modelos estéticos-narrativos e sua ideologia; produzindo-se então a hibridação intermedial ou seja o cruzamento do corpo teatral com a virtualidade do filme que expande a teatralidade.

Palavras chave: formas cênicas liminares - teatralidade expandida - teatro pós-colonial. 